\title{
RETHINKING JACQUES DERRIDA'S DECONSTRUCTION AND ITS RELEVANCE TO THE STUDY OF ISLAM
}

\author{
Abdul Fattah \\ State Islamic University of Mataram \\ Email: fath_smart@yahoo.com
}

\begin{abstract}
This article examines Jacques Derrida's concept of deconstruction and its implementation in the context of contemporary Islamic studies. Philosophically, the status of texts should not be regarded merely as writing because the meaning goes beyond the lexicogrammatical boundaries. Hence, scrutinizing ways to unveil hidden meanings possibly entail subjective or partial values embedded in the texts, particularly religious texts pertinent to Islamic civilization (turäth). Based on the philosophical analysis of the Derrida's work, this study shows that there are at least two points of the relevance of the Derrida's philosophical thought to deconstruct the turāth and the Western domination in Muslim society. First, it is a useful device to criticise and deconstruct religious thoughts and texts, which are, to some extent, still dominant and considered sacred. These cover a wide range of Islamic texts that build Islamic civilization, from mysticism, law to theology. The second dimension is dismantling the context (today Muslim civilization) through decentralization of the Western hegemony and promotion of Occidentalism, a way of seeing the West from the East.
\end{abstract}

Keywords: Derrida, deconstruction, turāth, occidentalism, Western hegemony

DOI: https://doi.org/10.20414/ujis.v23i1.349

\section{Introduction}

THE IDEA of the end of philosophy is closely related to the emergence of the concept of "deconstruction". Initially, the term was coined by the famous German philosopher, Martin Heidegger. He writes that "construction" in the philosophy by itself should be 
simultaneous "destructive", namely deconstruction of traditional concepts in a way that is precisely a return to tradition. ${ }^{1}$

Deconstruction as the newly emerging philosophical term became popular later through the work of French philosopher, Jacques Derrida, ${ }^{2}$ who formulated this concept systematically and comprehensively and used it as a critical device to philosophical thought. ${ }^{3}$

This article seeks to examine the post-structural philosophical concept of "deconstruction" critically as it is advanced by Jacques Derrida. As one leading contemporary philosopher, Derrida's philosophical thinking deserves critical assessment and reexamination. It is for this reason, namely re-examination and contextualization, that this paper attempts to place Derrida's deconstruction in the context of Islamic tradition. There are some works and studies about Derrida's thoughts in relations to Islam. ${ }^{4}$ But none of these asks the question that this present study aims to proposes; how Derrida's concept of deconstruction is relevant to the study of Islam.

I suggest that his thought is useful to develop Islamic science. Derrida's deconstructive style can enrich Islamic philosophical thought and sharpen Islamic institution diversity. His deconstruction can be used to critically dismantle the problems of scientific structure of Islamic science legacy (turäth) as well as the Western hegemony in it.

${ }^{1}$ Martin Heidegger, The Basic Problems of Phenomenology, trans. Hofstadter (Bloomington: Indiana University Press, 1982), 23.

2 Jonathan Culler, On Deconstruction: Theory and Criticism after Structuralism (London: Routledge \& Kegan Paul, 1983), 86-87.

${ }^{3}$ I. Bambang Sugiharto, Postmodernisme: Tantangan bagi Filsafat (Yogyakarta: Kanisius, 1996), 44.

${ }^{4}$ Jacques Derrida et al., Islam and the West: A Conversation with Jacques Derrida (Chicago: The University of Chicago Press, 2008); Ian Almond, Sufism and Deconstruction: A Comparative Study of Derrida and Ibn 'Arabi (London and New York: Routledge, 2014). 


\section{Jacques Derrida's Life and His Works}

Jacques Derrida, a French philosopher, was born in El Biar, Algeria in $1930^{5}$ from a Jew family. ${ }^{6}$ He is an Algerian by birth and Jew but inherits French educational tradition. ${ }^{7}$ Derrida later is known as a French philosopher whose ideas have influenced the diversity of thought in sociology, philosophy, and literature, particularly concerning the implications of the application of the methodology in human language. ${ }^{8}$ Deep experiential learning and teaching in various universities help Derrida becomes a master of philosophy. He died for cancer on October 9, 2004, at the age of $74 .{ }^{9}$

Derrida is a lecturer, philosopher and prolific author. In 1962, Derrida published a translation of Husserl's essay "The Origin of Geometry" and gave an introduction. In 1967, he published three works, namely L'ecriture et la Difference (writing indifference), and De La Grammatologie (about grammatology), which is a collection of essays in which most have been published in various periodicals. While his other work is "La Voix et le phenomena, Introduction au problem du signe Dans la Phenomenologie de Husserl (voice and phenomena, introduction to the problem of signs in phenomenology Husserl). This work comments at length on Husserl description about the "Signs" in his work "Research Logic" (precisely in chapter 1 of Article 1-9). ${ }^{10}$

In 1972, he also published some works. These include "Marges de la Philosophie" (Edges Philosophy), that presents a series of

${ }^{5}$ J.O. Urmson, The Concise Encyclopedia of Western Philosophy and Philosophers (Canada: Western University Canada, 1975), 71.

${ }^{6}$ Peter Beilharz, ed., Teori-Teori Sosial: Observasi Kritis Terhadap Para Filsuf Terkemuka, trans. Sigit Jatmiko (Yogyakarta: Pustaka Pelajar, 2002), 73.

${ }^{7}$ Robin Usher and Richard Edward, Postmodernism and Education (London and New York: Routledge, 1994), 132.

${ }^{8}$ David Jarry and Julia Jary, The Harpercollins Dictionary of Sociology (New York: Harpercollins Publishers, 1991), 118.

9 See Afid Burhanuddin and Siti Muthmainnah, "Derrida: Biografi dan Pemikiran," Afid Burhanuddin, September 21, 2013, accessed March 10, 2019, https://afidburhanuddin.wordpress.com/2013/09/21/derrida-biografi-danpemikiran/.

${ }^{10}$ K. Bertens, Filsafat Barat Kontemporer Prancis (Jakarta: Gramedia Pustaka Utama, 2001), 326. 
studies on Heidegger, Hegel, Husserl, Valery (French Poet), Aristotle, Austin and others. His work "La Dissemination (Spread)" includes the study of Plato and Mallarme (French Writer). While his other work, "Positions", collects three interviews with Derrida. ${ }^{11}$ In 1973, he published a lengthy introduction to the new edition of the book "Essai sur I'Origine des Connaisances Humanies (The attempt to explain the origins of human knowledge) by Ede Condillac, a French philosopher of the $18^{\text {th }}$ century. Later this preliminary issue arose as a separate book in 1976 under the title L'archeologie du Frivole (Archaeology on Frivolous).

His quite striking work is Glas (1974). Each page of it consists of two columns; the left is presented to give comments on Hegel texts about the family, while the right side on Jean Genet (a French writer). Other Derrida's work is Eperons (1976), Eperons, les styles de Nietzsche (1978), and la carte postale de Socrate a Freud et au-dela (1980)..$^{12}$

Most of Derrida's essays gained critical comments from philosophers, scientists and scholars. As a critical philosopher, Derrida does not accept interpretation for granted and limit himself to a particular thought. By commenting on those works, Derrida aims to propose a new idea. He set a new text and dismantle other texts. Thus, he tries to exceed the texts by saying something that is not said in the texts themselves. This is what he terms as "deconstruction", ${ }^{13}$ which seeks to find entities implied behind the text, making the text more dynamic and richer.

\section{Derrida's Deconstruction in the Western Philosophy}

Basically, "deconstruction" is a translation of two German words, used in the work of Martin Heidegger's "Being and Time" (1997), namely "Destruktion" and "Abbau". According to Heidegger, the most crucial philosophical issue is about the meaning of "being" that has been forgotten by the Western tradition of thought. It needs to be pared back adequately. History of philosophy is conceived of the history of concealment over "being". All

\footnotetext{
${ }^{11}$ Ibid., 326-327.

${ }^{12}$ Ali Mudhofir, Kamus Filsuf Barat (Yogyakarta: Pustaka Pelajar, 2001), 123.

${ }^{13}$ Bertens, Filsafat Barat, 328.
} 
philosophical concepts, such Plato's theory of Form, Descartes's Cogito, and Hegel's Spirit, just to mention some, have one common characteristic, namely failure to understand the meaning of "being" correctly.

Thus, the tradition has a metaphysical character. According to Heidegger, metaphysics arise from differences on two things uncritically, between "being" and "beings" and between "ground" and "the grounded", which occur during this time. The Western tradition considers "being" as a basis for "Beings". Then, Heidegger insists that now the tradition has not been abandoned or removed. We grow out of this tradition and cannot escape from it. Our job is to loosen its structures so that we can scrutinize them, and then reformulate the concept of "being". The demolition process of dismantling the tradition refers to what Heidegger terms "Destruction" and "Abbau". Later these terms are adopted by Derrida, who combines them into a single word of "Deconstruction". ${ }^{14}$

Deconstruction is an approach to the understanding of meaning by connecting existing words with other words. As proposed by Derrida and a number of Post-Structuralism defenders, the meaning of a language is not found in the concrete reality or truth. But the meaning is there laying in the relationship of language itself, which has been socially constructed. The term "masculine", for example, is not the name of a real truth that can be observed in human life, but the term "masculine" can only be identified through a mental process that connects it with other related terms, such as "feminine" or "androgynous".15

Deconstruction is usually formulated as a means or method of reading text. This is why this method has been developed and included in the field of literature. A typical thing in deconstructive readings on philosophical texts is the elements that have logical inconsistency and weak arguments or premises that are not convincing. But the reflective element is crucial, or the elements

${ }^{14}$ Beilharz, Teori-Teori Sosial, 74-75.

15 Allan G. Johnson, The Blackwell Dictionary of Sociology: User's Guide to Sociological Language (Cambridge: Blackwell Publishers, 1996), 71. 
that make a philosophical text important. So the possibility, philosophizing itself, is to be disputed. ${ }^{16}$

In this context, the philosophy is first assessed as "writing". As for writing, philosophy is never a transparent expression of an idea directly. There, always thinking embodied in the sign systems characterized by material, whether it is substance graph, or phonic (ink or sound) or something else. And in fact, the signs have also been used in many other contexts as writing and philosophy is always textual. That is, the unit is not the primary meaning of the word or sentence, but the sentence determines its meaning through association with other texts. ${ }^{17}$

In any philosophical writings, indeed, there is a sort of rational organizing efforts in order to intertwin premises, arguments, and conclusions neatly. However, the order of the text is not realized because it is the hidden assumptions behind the things that express it. In other words, Derrida attempts to show textually something hidden behind existing texts. ${ }^{18}$

While philosophy is basically writing, ambition of general philosophy is to escape from its status as the writing and out of the physical form of the language it uses. Derrida wants a language that uses it into a transparent tool that displays real meaning and truth that is extra linguistic. The way that is normally achieved is by reference to the basis of the purported "evidence" and organize the logic in such a way to appear intact, coherent and unambiguous. But for Derrida, all of "ambition" and that such efforts will never be likely to succeed. ${ }^{19}$

Deconstructive readings that aim to show the failure is by displaying hidden agendas that contain many weaknesses and lameness behind the texts. Then Derrida believes that behind the philosophical texts is hidden meaning, not avoid, but a different text, a diverse network of central forces whose reference is not clear. ${ }^{20}$

${ }^{16}$ Sugiharto, Postmodernisme, 44.

${ }^{17}$ Jacques Derrida, Position (Chicago: University of Chicago Press, 1981), 26.

${ }^{18}$ See again Sugiharto, Postmodernisme, 45.

${ }^{19}$ See Derrida, Position, 28-29.

${ }^{20}$ Jacques Derrida, Margin of Philosophy (Brighton: Hasvester Press, 1982), xxiii. 
As a way of reading texts, deconstruction is, however, different from the usual way of reading or interpretation to look for meaning or message of a text, even if such hidden meaning is more clearly than the meaning of the original text. Deconstruction is not doing that but instead of helping a text reaches its fullness by displaying its meaning. Deconstruction is the exact opposite that seeks to show lack of wholeness or failures of any text to cover themselves (e.g. by saying "this" and not "that"). Deconstruction wants to subvert the hierarchy of the conceptual structure of the text. Deconstruction is about to turn the hidden strengths that build a text. Through deconstruction, a text is no longer an integral meaning; it becomes a struggle between efforts "arrangement" and "chaos", that struggle to cope with the materiality of the text in order to achieve transparency, though sometimes in vain. In this manner, philosophy erodes. In other words, deconstruction seeks to transform our understanding about philosophy. ${ }^{21}$

If we reconstruct schematically, Derrida's deconstruction strategy consists of the following steps: first, identify the hierarchy of the opposition in the text, which is usually seen where the privileged terminology systematically is located. Second, oppositions are reversed by, for example, showing the interdependence between opposites, or by proposing a privilege in reverse. Third, the introduction of a new term or the idea that it cannot be put into the category of the old opposition. ${ }^{22}$

The tremendous implications of deconstruction philosophy are fading boundaries that have been rigorously maintained between the concepts with metaphors, between truth and physical, between philosophy and poetry. Such differences, no doubt, are a way of thinking of logocentrism. By deconstructive reading, we can say that the first part of each of the pair occupies a central position as the other parts are being marginalized, excluded and considered the "other". But the centre to get the fullness of identity is only by distinguishing itself with and issued away from "that are not central" from "not in", the centre and thus fully requires "the

${ }^{21}$ See again Sugiharto, Postmodernisme, 46.

22 See Derrida, Margin of Philosophy, 135. 
other", which is on the edge and outside. This means that the position "on edge" and "outside" actually "very central"and" very inside."23

Because "that is on edge" and "the outside" are actually very "in the centre" and "inside", it is no exaggeration if we say that the concept is a metaphor as well because the truth turned out to be no less than physical. Philosophy is a kind of poetry, and the seriousness is none other than the game. Everything was in the same medium. Language with the meaning is always delayed, ambiguous, paradoxical, and always in the dissemination. In other words, language is a "reality" because the reality may not be present without language. Language is also a "text" or "writing" with the understanding that it is impossible to refer to the origin of a single and standard word. ${ }^{24}$

Derrida's proclamation about the textual characteristics and "writing" in everything are apparently welcomed by prominent neo-pragmatists philosopher Richard Rorty. In the essay "Philosophy as a Kind of Writing", Rorty agrees with Derrida that the era of philosophy and epistemology, which seriously discuss and seek for the truth as the "Great Stories", has been completed. What we need now is a "Small Stories" such as novels and poetry, which no longer offer the truth, but the things that are interesting and exciting in life. If today there is philosophical discourse, should we need it as a genre of literature or as mere poetry. ${ }^{25}$

\section{Re-thinking Deconstruction in Islamic Studies}

It has been explained above, that Martin Heidegger is known with his "Phenomenology existentialist", thinking about loosening the structures of western metaphysics and reformulating the question of "being" more precisely. Easing the process and dismantling of a quaint tradition was referred to by Heidegger as "destruction". It needs to be clarified that the Jacques Derrida's

${ }^{23}$ Terry Eagleton, Literary Theory an Introduction (Oxford: Blackwell, 1987), 132.

${ }^{24}$ Nurcholish Madjid et.al., Dekonstruksi Islam Mazhab Ciputat, ed. Edy A. Effendy (Bandung: Zaman Wacana Mulia, 1999), 140.

${ }^{25}$ Christopher Norris, The Truth About Postmodernism (Oxford-Cambridge: Blackwell, 1993), 60-61. 
concept is against the "intellectual project". Basically, the reason, destroying the metaphysical meaning, is the same as building a new metaphysics, and this is a work in vain. We are only able to do deconstruction, whereas we shall be able to rearrange the basic concept entirely. That is why Derrida used the term "deconstruction" and not "destruction" as an obsession with the famous German philosopher Martin Heidegger.

More fundamentally, the deconstruction of Derrida drawn from the Phenomenology of Edmund Husserl is regarded as the panacea of modern metaphysical thinking. How Derrida deconstructs the Phenomenology of Edmund Husserl is primarily to use the language model of the father of modern linguistics, Ferdinand de Saussure. The main target is to deconstruct a phenomenological way of thinking about "being" and "presence". ${ }^{26}$

Husserl considers "being" of Western metaphysics legacy of ancient Greece as a direct presence. From here, we are as if face to face with the truth, then the truth itself becomes the "centre" of all human activities. This kind of thought process legitimizes Western thought about the concept of "centre", and then produces what we are familiar with the term "Westernization" and "Ethnocentrism". Thus, the West becomes the centre of world civilization. ${ }^{27}$

By thinking like that, "being" as a metaphysical concept becomes impossible. Or "being" in a concept like this in the linguistic concept of de Saussure is called the "signified", which is to do with shaping the language signifier. However, since the concept of "being" (signified) that has been considered as a reference to think is not possible, then we thus lose the concept of truth directly. Here, Derrida once deconstructs the structuralism of de Saussure language on the signifier-signified structure relationship. So Derrida is a Post-Structuralist. Then the metaphysics of the immediate presence that gives birth to centralism in Western thinking is dismantled with the concept of intertextuality, which means "decentralization".

${ }^{26}$ Tommy F. Awuy, "Dekonstruksi: Postmodern Dan Poststrukturalis," in Postmodernisme dan Masa Depan Peradaban, ed. Suyoto et.al. (Yogyakarta: Aditiya Media, 1994), 51.

${ }^{27} \mathrm{Ibid}$ 
Meanwhile, the concept of deconstruction by Derrida, who attempts to "satirize" Western thought, is a good indication of how history and philosophy are read from the position of the edge. The position excludes from history itself. In the context of Derrida, it is real. Derrida is an Algerian Jew-French-Western philosopher who enters history with a feeling, not as the owner. This is because Derrida is overshadowed by a broken identity. Derrida is Jewish at once. At the same time, he is also an Algerian but simultaneously not totally Algerian, and he is also a French but not fully a French. ${ }^{28}$ This condition makes Derrida highly suspicious of the tendency of centralization (which is meaningful and proprietary) that "entrenched" in Western metaphysics.

Based on it, it is a "misreading" clearly that people understand deconstruction ignoring alignments to the supplementary commitment, diversity and "otherness". That is, deconstruction is only understood as a specific way to read the texts of literature, philosophy, ancient texts or the like. If only limited to this, of course, deconstruction is " $d u d "$ of emancipation. Moreover, deconstruction should not be separated from its involvement with the problems of political institutions, namely a new strategy to examine the extent to which the structures are formed. ${ }^{29}$ Boundaries and unification are to be "subversive" by deconstruction strategy. The deconstruction paradigm of the problems of politics is at least proven by Derrida's involvement in political issues. He actively opposes political apartheid, supporting for Mandela, opposing the French government's efforts to reduce the philosophy course in high school, and becoming a vocal critic against violations of human rights, as well as promoting feminism. ${ }^{30}$

It is of impressive to try to connect such discussion of deconstruction to the Islamic scientific tradition. Derrida is not an unknown figure for contemporary Islamic discourse; therefore citing him to enforce critical thinking within Islamic science is an open call. Although there is controversy over his philosophical

28 See Madjid et.al., Dekonstruksi Islam, 141.

${ }^{29}$ Culler, On Deconstruction, 156.

30 See Madjid et.al., Dekonstruksi Islam, 142. 
thoughts, deconstruction seems to be a useful critical device in this respect.

Derrida's ideas can inspire Muslims in reading their religious texts and even deconstructing any hegemonic Islamic theologicalphilosophical and religious texts (especially theology, philosophy, tasawwuf, jurisprudence, and the results of the interpretation of scripture). Thus, this approach will avoid what Mohammed Arkoun terms as "taqdis al-afkār al-dìn", making religious thought sacred.

In this framework, I see the correlation of Derrida's deconstruction with the treasures of Islamic studies from two aspects.

\section{The Deconstruction of Religious Text (Turäth)}

This idea comes from Komarudin Hidayat, who contends that the text in the Islamic tradition is not confined to the Qur'an. The universe and behaviour (tradition) are itself a "religious" text, all of which stored and wanted to communicate the meaning and the message this tradition contains. Dialogical correlation occurs between the subject (Muslims), the text of the Qur'an, prophetic tradition, and the reality of the universe with its laws. Since it was first revealed, the Qur' an has made a radical deconstruction of the epistemology as well as the poetry of ignorance at that time. Then, the Qur'an introduces "Being" that underlies all the beings in various ways of dialogical and rational, rather than definitive and, positivist. ${ }^{31}$

The concept of "Being" introduced by the Qur'an refers to God as the universal God. Based on the Qur'an, Al-Ghazali in his book "Ninety-Nine of God Names", clearly distinguishes between the "name", "naming", and "the named". God as "absolute reality" may not be understood by human beings, except indirectly, partial, and relational, namely through the "traces" of His work which then connect people to appreciate God according to their intelligence, psychological and ethical situations. If God as the absolute reality can be understood as "natural" or can be "presented" as the present

${ }^{31}$ See Komaruddin Hidayat, Tragedy Raja Midas: Moralitas Agama dan Krisis Modernisme (Jakarta: Paramadina, 1998), 157. 
positivistic reality, then it means that God has been dominated by a relative being. This means that God is no longer an "absolute being".

According to Hidayat, there are several reasons why it is necessary to deconstruct the language of religion and how it can be conducted. First, the holy book as the word of God is revealed in the specific time and space, while humans as targets or "service users" are continually evolving in civilization. With the culmination of civilization heritage hereditary, modern society can develop without reference to scripture, so that the position of scripture may be getting stranger.

Second, any language, including the language of scripture, has local limitations. Because language is a cultural reality, the message and truth contained in the local language have no universal claim. The religious language will be tested sophistication to save the religious message without having occurred anomaly or shackled by the vehicle uses.

Third, the language of religion as "sacred" will generate a few possibilities. It could be the message of religion that will be maintained firmly, but the meaning and the message of religion are fundamental. It is hemmed in by text that has "sacred" it.

Fourth, the holy book, in addition to the codification of the law of God, is a "record" dialogue of God with history where God's presence is represented by His apostles. When the dialogue is written, it is possible that there has been a reduction and impoverishment of shades, so the dialogue between God and man was lost, and after years it was rewritten in the form of texts.

Fifth, more autonomous and developed human thoughts are, the more autonomous human being to follow or reject the teaching of religion and its holy book. Moreover, when one reads the text of scripture, what may actually happen is a process of critical dialogue between two subjects. Thus, people, instead of interpreting, are asking for a fatwa (advice) on the holy book, and the place of the scriptures as a friend dialogue free of domination. ${ }^{32}$

32 See Ibid., 158-159. 
Thus, without deconstruction and critical attitude towards the building of religious epistemology and language, it could be that readers are "prisoner" of language while the language should be a "bridge" to cross beyond the symbols and text. In the context of religious language, Hidayat made three fundamental characteristics; First, the object of the language of religion, especially Theo-oriented, metaphysical, is centred on God and the world of a new life beyond the death. Second, as the implications of the first, format and subject matter of religious narrative are the holy book. Third, the language of religion and religious expression includes expression from individual or groups, including the expression mother tongue. The three characteristics of religious language offer positions the role of languages like the spirit or the inspiration to live and move in the human body. ${ }^{33}$

Through such deconstructive reading to the Islamic religious texts, as proposed by Hidayat above, the deconstruction of the language of religion can be made. However, deconstruction here seems to be a move to do the "reconstruction" of the conceptual and spiritual ascent toward "absolute reality".

Further, according to An-Na' $\mathrm{im}^{34}$ and al-Jabiri, ${ }^{35}$ what need to do for reform is the classical Islamic texts produced by classical and medieval scholars. Meanwhile, Muslim philosopher Mohammed Arkoun refers this to "orthodoxy". Arkoun perceived further that Islamic tradition linked to the concept of orthodoxies, such as Islamic theology (kalam), tasawwuf, and fiqh, is actually a set of idea belonging to ordinary humankind that should not be seen as sacred. Those legacies are thus not sacred and can be reread and criticize. ${ }^{36}$ Therefore, the hegemony of Islamic tradition,

33 See Madjid et.al., Dekonstruksi Islam, xxvi.

${ }^{34}$ See Abdullah Ahmed al-Na'im, Dekonstruksi Syari'ah: Wacana Kebebasan Sipil, Hak Asasi Manusia, dan Hubungan Internasional dalam Islam, trans. Ahmad Suaedy and Amiruddin Arrani (Yogyakarta: LKiS in cooperation with Pustaka Pelajar, 1994), 138.

${ }^{35}$ Look at his prominent work, Mohammed Abed al-Jabiri, The Formation of Arab Reason: Text, Tradition and the Construction of Modernity in the Arab World (London: I.B. Tauris, 2011).

36 Masnun Tahir, "Studi Hukum Kritis Dalam Kajian Hukum Islam," Istinbath: Jurnal Hukum Islam 13, no. 2 (2014): 211, https://www.neliti.com/ publications/41832/studi-hukum-kritis-dalam-kajian-hukum-islam. 
specifically in the form of religious text (turāth), is "lawful" to be analyzed, criticized, examined, even dismantled or deconstructed to produce new understanding and genuine interpretation that free from the hegemony of orthodoxy.

In a pile of religious texts, especially in figh, for example, there are a number of orthodox texts that need to be criticized or even deconstructed to provide alternative interpretations more relevant to the modern aspiration and complexity of contemporary challenges of Muslim religious, social, cultural and economic life. Some classical thoughts in Islamic law, for example, exemplify such problems that call for deconstruction. Take for examples the following precepts: (1) A Muslim man may marry a Christian or Jewish woman, but a Christian or Jewish man may not marry a Muslim woman, ${ }^{37}$ (2) Religious differences are a barrier to all inheritance, so that a Muslim cannot inherit from or bequeath to non-Muslims and vice versa, (3) Muslim men can marry up to four women at the same time, while a Muslim woman can only marry a man at the same time, ${ }^{38}$ (4) Two female witnesses are equivalent to one male witness. ${ }^{39}$ The other examples can also be seen in the issues relating to family leadership ${ }^{40}$ and dress code and guardian and. ${ }^{41}$ These are based on the Qur'an. However, the meanings of those verses maybe not as simple as interpreters understand them. Looking at the spirit of Islam and the Qur'an on the principle of equity and equality, just, fairness and equality of human before God, it is very likely that any simplistic understanding of those verses is re-examined.

Some of the examples above clearly show that in the religious text or turāth there is discrimination of human rights based on the gender of women and non-Muslims in family law. And these are the most severe points of conflict and tension between sharia and universal human rights. A critical approach in interacting with Islamic legal texts will provide an opportunity to see

\footnotetext{
${ }^{37}$ Look at Qs. Al-Maidah [4]: 41.

${ }^{38}$ Look at Qs. an-Nisa '[4]: 3 and the end of verse 129.

${ }^{39}$ (Qs. al-Baqarah [2]: 282).

${ }^{40}$ (Qs. an-Nisa '[4]: 34).

${ }^{41}$ Look at Qs. al-Ahzab [33]: 59; Qs. an-Nisa' [4]: 15.
} 
proportionally existing legal formulations without having to position them as sacred texts.

In sum, deconstruction as a critical method can dismantle interests and ideologies that are no longer relevant to the contemporary world. Issues regarding gender inequality, human rights, and plurality are some of the issues that must be considered for the new formulation of religious text (turäth) which are already well established. So, criticism and deconstruction must be carried out to discover the true spirit of Islamic law, fiqh, tasawwuf, and others which has been covered by the interests and ideology of the formulator in the past.

\section{Occidentalism: Dismantling Western Hegemony}

Western hegemony in the modern era seems to be inevitable. All aspects of life are hardly removed from such domination. ${ }^{42}$ The hegemony of Western civilization can be categorized into several forms. First is the hegemony of culture, such as "McWorld phenomenon", a jargon that was very familiar in the ears of the 1970s and 1980s generations. McWorld is a combination of three big icons that hold the world of MTV for music, McDonald for the food, and Macintosh for the information centre. The phenomenon of McWorld is one of the facts that the world is experiencing globalization. ${ }^{43}$ Second, the hegemony of the economy. Western and developed countries control most of the economic resources. Economic bubble in this era of globalization is very difficult to avoid. Some of the reasons are due to the unbalanced turnover of money with the turn of goods and services. This happens because of the rampant speculative business (in the world of capital markets, the forex market and property) which is not matched by the flow of goods and services. ${ }^{44}$

${ }^{42}$ Feriyadi Feriyadi and Syamsul Hadi, “Hassan Hanafi's Response to Western Hegemony in Muqaddimah Fī 'Ilmi Al-Istighrāb Through Hegemony Theory of Gramsci," IJISH (International Journal of Islamic Studies and Humanities) 1, no. 1 (April 7, 2018): 50, accessed March 29, 2019, http://journal2.uad. ac.id/index.php/ijish/article/view/133.

${ }^{43}$ See also Ibid., 51.

${ }^{44}$ Ibid. 
Third, the hegemony of technology and mass media. The Western mass media supported by information technology plays a vital role in instilling feelings of fear of Islam. The term "Terrorism", for example, has become a public discourse depicting barbaric acts of perpetrators of violence that is later easily associated with Muslims. In addition, the West also controls the technology market for electronic goods. Thus, the mastery of technology and mass media has a dominant role in the spread of the hegemony of Western civilization. ${ }^{45}$ But above all for the Islamic world, according to Hassan Hanafi, the most dangerous is the hegemony of religion or thought. ${ }^{46}$

Hanafi is thus well known among the Muslim scholars who have a strong obsession in decentralizing the Western hegemony. Hanafi is an Egypt-based Muslim scholar who studied in Paris. After his long intellectual odyssey in the Western world, Hanafi criticizes the West, which previously became guidance and inspiration in constructing his thoughts. Occidentalism is one of his impressive ideas which can be a representative voice of the Eastern world in dismantling the hegemonic Orientalism. ${ }^{47}$

In "Al-Yasar al-Islām" (The Left of Islam/Islamic Left), he strongly criticized the dominance and hegemony of the West. In this work, he relates the weak and the oppressed as the impact of European colonialism and imperialism. Hanafi also notes that by the "Islamic left", he meant as opposed to the dominant West, that tends to become a global standard or normativity. Whereas, the West cannot be equated as the best standard for morality, religiosity and spirituality.

It is, therefore, necessary to raise a counter-discourse to the West, and the East must determine their own history and discourse. The East must not become the subject/object of inquiry

45 Tony Bennett, Culture, Ideology and Social Process: A Reader (London: Batsford Academic and Educational in association with the Open University Press, 1981).

${ }^{46}$ Hasan Hanafī, Oksidentalisme: Sikap Kita terhadap Barat, trans. M. Najib Buchori (Jakarta: Paramadina, 2000), 18.

47 Ridho Al-Hamdi, "Hassan Hanafi's Epistemology on Occidentalism: Dismantling Western Superiority, Constructing Equal Civilization," Epistemé: Jurnal Pengembangan Ilmu Keislaman 14, no. 1 (June 15, 2019): 77. 
from the West with its values, method and epistemology. In contrast, the East can also study the West, depicting, criticizing and representing it in accordance with the Eastern perspective. Edward Said has initiated such criticism to the West and Hanafi attempted to establish a scientific formula to implement this. Occidentalism (al-ilm al-istighrab) represent the new field of though to achieve that end. If Orientalism is the study of the Eastern and Islamic civilization by researchers from the perspective of the Western civilization that have a different structure with that of the civilization reviewed (the East), then Occidentalism is the reverse; it sees the West from the perspective of the East. 48

Orientalism is a kind of intellectual hegemony that escorts cultural and political domination and power, while Occidentalism purports to see the West as an object of academic inquiry. In other words, it wants to liberate the East from the West cultural and epistemological domination. Occidentalism is built on "ego" that is neutral from ambition and power. It asks for liberation. ${ }^{49}$ The main task of this new paradigm of Occidentalism by Hanafi is to restore the emotional non-European to its original place, eliminating the alienation and placing it in a realistic position. This will lead to a stance against the civilization of Europe, which was claimed as a source of knowledge and the centre of civilization. It is the domination of one civilization to the other that incite resistance in this era of revitalization and resurgence. ${ }^{50}$

There are five standards of the truth in Hanafi's

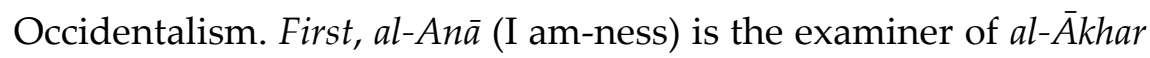
(the other-ness). A long time ago, the East was the examiner of Greece, while Europe is the examiner of the East, and now the East retakes the position as the examiner of Europe. Second, it eliminates the claim of Europe as the cosmopolite culture of the world, which should be obeyed by others. There is no claim on the centre of culture and the branch of culture. It should be a reciprocal relationship between them. Third, European

${ }^{48}$ Hasan Hanafi, Muqaddima fi 'Ilm al Istighrab (Beirut: al-Hamra', 1992), 25.

${ }^{49}$ See Ibid.

50 See again Ibid., 26. 
consciousness is the object of study. Due to the long process of the formation of this consciousness, Hanafi applies two methods, namely dialectical history and phenomenology, to place the European consciousness in its natural limits. Fourth, Selfliberation. One of the Occidentalism missions is the spirit of selfliberation of al-Anā from the domination of al-Ākhar. It indicates that $a l-A n \bar{a}$ has been in the oppression era, which has not ended. This situation affects al-Anā to have no ability to do anything, even almost lose its own identity - fifth, Equal civilization. The final goal of Occidentalism is an equal civilization. No one is dominating, and none of them is dominated by the other. All civilizations are in an equal position for collaboration. ${ }^{51}$

What is going to be pursued by Hanafi on decentralization of the Western domination or hegemony through Occidentalism has similarities with the concerns of Derrida who sees a strong enough affinity between the notions of universal ethics to violence. Affinity is closely related to the basis of thought itself, namely the Western philosophy and metaphysics. Their tradition of thinking "Egocentrism" has prompted the Western philosophy to be totalitarian as the centre and others are different subordinate. This perception will eventually silence "the otherness" and the difference. Derrida's thesis is reinforced by Edward Said.52 For Said, the idea of humanism, a subject that is free, and the principle of rationality that accompany modern western ideas and universal claimed, turns in its history to contain ethnic prejudices and acute nationalism. This prejudice is even experienced by the humanist philosophers themselves. Alexis de Tocquiville for example, is the father of the famous American Democracy denounced American slavery. But his support to one of European governments against a Muslim regime in north Africa, ${ }^{53}$ shows inconsistencies of the West (including those from the Intellectuals) in reading and responding to "the other" (read: the East-Islam).

${ }^{51}$ See again Ibid. and Al-Hamdi, "Hassan Hanafi's Epistemology," 100.

52 See Daniel Martin Varisco, Reading Orientalism: Said and the Unsaid (Seattle and London: University of Washington Press, 2007).

53 Edward W. Said, “Nationalism, Human Right, and Interpretation," in Freedom and Interpretation: The Oxford Amnesty Lectures, ed. Barbara Johnson (New York: Basic Books, 1993), 186-188. 


\section{Conclusion}

This paper has elaborated Derrida's concept of deconstruction and its relevance to Islamic studies. The most popular concept of Derrida, however, is about "difference", a notion which is very difficult to explain as Derrida himself said "this is neither a concept nor a word". The reason is because every word and concept entwined in a series of concept (or set of words) in which each concept refers to other concepts in a "game" of differences. This can be a topic for other studies that want to examine or relate "the difference" to Islamic studies.

In the context of Islamic studies, Jacques Derrida's deconstruction can be seen from two sides, (1) deconstruction of religious language/ text (turāth), and (2) decentralization of the Western hegemony. In the first context, when Muslims read the scriptures/religious text (turāth), the reading actually means a critical dialogue between the two; readers and texts. In this creative nuance, instead of giving the interpretation or asking for advice on the holy book, this method positions the scripture as a dialogue partner, not as dominating religious doctrine.

Meanwhile, the deconstruction in Hanafi's Occidentalism aims to dismantle the Western hegemony of the East (Islam). Hanafi sees a disproportional perception that puts Western culture as the standard of truth in every dimension of life. This perception must be denied, and the East must liberate themselves from the West. Within this framework, Occidentalism mandates the expression of "ego" as an emotion that is neutral to view "the other" (read: West): studying and turning it into an object and after all this time "the other" (West) became the subject (through the study of Orientalism) for itself. This method is not an ambitious usurper of Western domination but requires liberation of the East from Western domination.

\section{References}

Al-Hamdi, Ridho. "Hassan Hanafi's Epistemology on Occidentalism: Dismantling Western Superiority, Constructing Equal Civilization." Epistemé: Jurnal Pengembangan Ilmu Keislaman 14, no. 1 (June 15, 2019): 75-108. 
Almond, Ian. Sufism and Deconstruction: A Comparative Study of Derrida and Ibn 'Arabi. London and New York: Routledge, 2014.

Awuy, Tommy F. "Dekonstruksi: Postmodern Dan Poststrukturalis." In Postmodernisme dan Masa Depan Peradaban, edited by Suyoto et.al. Yogyakarta: Aditiya Media, 1994.

Beilharz, Peter, ed. Teori-Teori Sosial: Observasi Kritis Terhadap Para Filsuf Terkemuka. Translated by Sigit Jatmiko. Yogyakarta: Pustaka Pelajar, 2002.

Bennett, Tony. Culture, Ideology and Social Process: A Reader. London: Batsford Academic and Educational in association with the Open University Press, 1981.

Bertens, K. Filsafat Barat Kontemporer Prancis. Jakarta: Gramedia Pustaka Utama, 2001.

Burhanuddin, Afid, and Siti Muthmainnah. "Derrida: Biografi dan Pemikiran." Afid Burhanuddin, September 21, 2013. Accessed March 10, 2019. https://afidburhanuddin.wordpress.com/ 2013/09/21/derrida-biografi-dan-pemikiran/.

Culler, Jonathan. On Deconstruction: Theory and Criticism after Structuralism. London: Routledge \& Kegan Paul, 1983.

Derrida, Jacques. Margin of Philosophy. Brighton: Hasvester Press, 1982.

- - - Position. Chicago: University of Chicago Press, 1981.

Derrida, Jacques, Mustapha Cherif, Teresa Lavender Fagan, and Giovanna Borradori. Islam and the West: A Conversation with Jacques Derrida. Chicago: The University of Chicago Press, 2008.

Eagleton, Terry. Literary Theory, an Introduction. Oxford: Blackwell, 1987.

Feriyadi, Feriyadi, and Syamsul Hadi. "Hassan Hanafi's Response to Western Hegemony in Muqaddimah Fī 'Ilmi Al-Istighrāb Through Hegemony Theory of Gramsci." IJISH (International Journal of Islamic Studies and Humanities) 1, no. 1 (April 7, 2018): 47-56. Accessed March 29, 2019. http://journal2.uad. ac.id/index.php/ijish/article/view/133.

Hanafī, Hasan. Muqaddima fi 'Ilm al Istighrab. Beirut: al-Hamra', 1992. 
- - - Oksidentalisme: Sikap Kita terhadap Barat. Translated by M. Najib Buchori. Jakarta: Paramadina, 2000.

Heidegger, Martin. The Basic Problem of Phenomenology. Translated by Hofstadter. Bloomington: Indiana University Press, 1982.

Hidayat, Komaruddin. Tragedy Raja Midas: Moralitas Agama dan Krisis Modernisme. Jakarta: Paramadina, 1998.

al-Na'im, Abdullah Ahmed. Dekonstruksi Syari'ah: Wacana Kebebasan Sipil, Hak Asasi Manusia, dan Hubungan Internasional dalam Islam. Translated by Ahmad Suaedy and Amiruddin Arrani. Yogyakarta: LKiS in cooperation with Pustaka Pelajar, 1994.

al-Jabiri, Mohammed Abed. The Formation of Arab Reason: Text, Tradition and the Construction of Modernity in the Arab World. London: I.B. Tauris, 2011.

Jarry, David, and Julia Jary. The Harpercollins Dictionary of Sociology. New York: Harpercollins Publishers, 1991.

Johnson, Allan G. The Blackwell Dictionary of Sociology: User's Guide to Sociological Language. Cambridge: Blackwell Publishers, 1996.

Madjid et.al., Nurcholish. Dekonstruksi Islam Mazhab Ciputat. Edited by Edy A. Effendy. Bandung: Zaman Wacana Mulia, 1999.

Mudhofir, Ali. Kamus Filsuf Barat. Yogyakarta: Pustaka Pelajar, 2001.

Norris, Christopher. The Truth About Postmodernism. OxfordCambridge: Blackwell, 1993.

Said, Edward W. "Nationalism, Human Right, and Interpretation." In Freedom and Interpretation: The Oxford Amnesty Lectures, edited by Barbara Johnson, 186-188. New York: Basic Books, 1993.

Sugiharto, I. Bambang. Postmodernisme: Tantangan bagi Filsafat. Yogyakarta: Kanisius, 1996.

Tahir, Masnun. "Studi Hukum Kritis Dalam Kajian Hukum Islam." Istinbath: Jurnal Hukum Islam 13, no. 2 (2014): 202-214. https://www.neliti.com/publications/41832/studi-hukumkritis-dalam-kajian-hukum-islam. 
134 Llumunz, Vol. 23, No. 1 (2019)

Urmson, J.O. The Concise Encyclopedia of Western Philosophy and Philosophers. Canada: Western University, Canada, 1975.

Usher, Robin, and Richard Edward. Postmodernism and Education. London and New York: Routledge, 1994.

Varisco, Daniel Martin. Reading Orientalism: Said and the Unsaid. Seattle and London: University of Washington Press, 2007. 